\title{
EDUKASI SELF-CONCEPT MELALUI KOMUNIKASI ANTARPRIBADI ANTARA ORANG TUA DENGAN ANAK PADA KEGIATAN PENGABDIAN "HAYU URANG NGOBROL, DAK..."
}

\author{
Dianingtyas M. Putri ${ }^{1 *}$ \\ ${ }^{1}$ Program Studi IImu Komunikasi, Fakultas Ekonomi dan Ilmu Sosial, Universitas Bakrie \\ JI. HR. Rasuna Said Kav. C-22 Kuningan Epicentrum, Jakarta Selatan, 12920. Tlp: 021-5261448 \\ *Email: dianingtyas.putri@bakrie.ac.id
}

Received: April 18, 2020 / Revised: May 28, 2020 / Accepted: June 30, 2020

DOI: https://doi.org/ 10.36782/ijsr.v2i1.30

\begin{abstract}
ABSTRAK
Menjadi orang tua adalah tugas yang tidak mudah, apalagi jika orang tua belum memiliki bekal cukup untuk mendidik anak. Salah pengasuhan yang dimaksudkan adalah salah pola asuh, akan membuat proses tumbuh kembang pada diri anak baik secara psikis dan mental akan membentuk konsep diri (self-concept) negatif, sehingga akan memengaruhi penghargaan diri (self-esteem), efikasi diri (self-efficacy) juga negatif. Minimnya pengetahuan parenting yang dimiliki oleh orang tua untuk mendidik anak-anaknya, juga merupakan salah satu hambatan utama dalam proses tersebut. Kegiatan Pengabdian Kepada Masyarakat (PKM) kali ini dilakukan di desa Karya Mekar Kecamatan Cariu Kabupaten Bogor, dimana faktor lingkungan sosial, status ekonomi, serta model pengasuhan yang salah diturunkan kembali pada penerusnya. Selain itu, latar belakang pendidikan orang tua nya hanya ditamatkan Sekolah Menengah Pertama (SMP), sebagian lagi Sekolah Dasar (SD) saja, kemudian berakhir dengan melanjutkan hidup dengan menikah di usia muda 22-35 tahun. Tujuan dilakukan kegiatan pengabdian untuk memberikan pemahaman mengenai peran komunikasi antarpribadi dalam proses pembentukan konsep diri. Metode pelaksanaan dilakukan berupa parenting education yang dikemas dengan interactive experience sharing, disini juga akan melibatkan mahasiswa untuk mengintepretasikan materi menggunakan bahasa lokal, agar dimengerti oleh peserta. Hasil kegiatan menunjukkan bahwa peserta memahami pengemasan pesan dari teori dasar komunikasi $5 \mathrm{~W}+1 \mathrm{H}$ yang harus dilakukan saat interaksi komunikasi dengan anak mereka. Selanjutnya, peserta dibekali pengetahuan mengenai cara menciptakan iklim komunikasi yang kondusif dengan anak agar tercipta rasa saling menghargai dengan menghindari kalimat yang destruktif yang bisa berdampak pada self-concept, self-esteem hingga self-efficacy mereka.
\end{abstract}

Kata Kunci: interactive experience sharing, komunikasi antarpribadi, parenting education, self-concept, self-esteem

\section{ABSTRACT}

Being a parent is not an easy task, especially if parents do not have enough stock to educate children. One of parenting that is intended is wrong parenting, will make the process of growth and development in children both psychologically and mentally will form a negative selfconcept, so that it will affect self-esteem, self-efficacy is also negative. The lack of parenting knowledge possessed by parents to educate their children is also one of the main obstacles in 
the process. The Community Service (PKM) activity this time was carried out in the village of Karya Mekar, Cariu District, Bogor Regency, where social environmental factors, economic status, and the wrong model of parenting were handed downd to their successors. Also, his parents educational background was only completed by junior high school (SMP), some elementary schools (SD) only, they ended by continuing to live by getting married at a young age of 22-35 years. The purpose of service activities is to provide an understanding of the role of interpersonal communication in the process of forming self-concepts. The method of implementation is carried out in the form of parenting education, which is packaged with interactive experience sharing, here will also involve students to interpret the material using local languages, so that participants can understand. The results of the activity show that participants understand the packaging of messages from the basic theory of communication $5 W+1 H$ to do during the interaction of communication with their children. Furthermore, participants are provided with knowledge on how to create a conducive communication climate with children to create mutual respect by avoid destructive sentence that can have an impact on their self-concept, self-esteem, self-efficacy.

Keyword: interactive experience sharing, interpersonal communication, parenting education, self-concept, self-esteem

\section{PENDAHULUAN}

\section{Latar Belakang}

Menjadikan anak yang berhasil dan sukses adalah impian semua orang tua, namun dalam prosesnya tak jarang orang tua memaksakan anak-anak untuk harus sesuai dengan kemauan orang tuanya. Ditemukan dari hasil penelitian yang dilakukan oleh Anchor Boneeto tentang sikap, perilaku, aspirasi, dan figur panutan anak Sekolah Dasar (SD) antara usia 7-12 tahun dalam artikel yang dituliskan oleh cnnindonesia.com dengan judul Sebagian Besar Anak Indonesia 'Salah Asuh', mengungkapkan fakta bahwa anakanak Indonesia cenderung dibesarkan dengan keterbatasan sosial. Dokter Spesialis Anak Konsultan Tumbuh Kembang Soedjatmiko juga mengatakan anak-anak yang berusia 7-12 tahun ini menyampaikan faktor terjadinya keterbatasan sosial adalah adanya tekanan sosial dari lingkungan internal maupun eksternal, dan semata-mata hanya berfokus pada pencapaian akademis sehingga menghambat pertumbuhan bakatnya, sebutnya dalam acara peluncuran kampanye 'Tumbuh Aktif, Temukan Hebatmu' di The Palace, Lotte Shopping Avenue.

Dengan pola asuh yang cenderung bersifat tradisional ini menjelaskan juga bagaimana tekanan dari significant others yakni orang tua, keluarga ataupun kerabat dekat untuk menuntut sesuai dengan yang diinginkan. Pada dasarnya, anak dilahirkan dan dibesarkan oleh orang tua. Hal yang serupa disampaikan dalam jurnal kependudukan Indonesia dengan judul "Menilik Ulang Arti Keluarga Pada Masyarakat Indonesia" 
oleh Amorisa Wiratri disebutkan Kementerian Kesehatan Republik Indonesia mendefinisikan keluarga sebagai unit terkecil dari masyarakat yang terdiri atas kepala keluarga dan beberapa orang yang terkumpul dan tinggal di suatu tempat di bawah satu atap dalam keadaan saling ketergantungan. Kajian oleh Puspitawati (2008) mendefinisikan keluarga sebagai unit sosialekonomi terkecil dalam masyarakat yang merupakan landasan dasar dari semua institusi. Selain itu, keluarga juga dipahami sebagai kelompok primer yang terdiri dari dua orang atau lebih yang memiliki jaringan interpersonal, hubungan darah, hubungan perkawinan. Minimnya pendidikan orang tua dalam pola asuh anak, membuat minimnya pengetahuan parenting yang tepat untuk diterapkan pada penerus mereka. Pendidikan diawali dari keluarga, orang tua dan rumahlah yang menjadi sekolah pertama yang dikenal oleh anak. Edwin, dkk (1960) dalam bukunya yang berjudul Principles of Criminology menuliskan melalui orang tualah, anak akan belajar mengenai nilainilai dan norma. Disini, akan dikenalkan dengan nilai (value) yang dasar yang diturunkan dari kelompok terkecil yakni keluarga, sehingga nilai ini akan menjadi budaya dan akan memengaruhi norma manusia dalam perkembangannya.

Oleh karena itu, kaitannya dengan proses perkembangan diri anak maka selama proses pembentukan konsep diri, hal pertama yang akan dilalui diri seorang anak adalah masa meniru,
Thalib (2010) menyampaikan secara psikologis disini mereka akan meniru perilaku orang dewasa bisa orang tua, kakak, dan sebagainya karena apa yang mereka lihat dan dengar, akan ditiru oleh anak.

Parenting education seperti yang disampaikan oleh Arumsari, dkk (2018) sangat dibutuhkan dengan metode yang tepat bagi orang tua dalam membantu pembentukan konsep diri, sebab orang tua bukan hanya berperan sebagai orang tua namun juga sebagai pembimbing bagi anak. Parenting oleh Silalahi (2010) tidak hanya sekedar mengasuh anak, tetapi orang tua juga harus mendidik, membimbing, serta melindungi setiap perkembangan dari si anak, khususnya konsep diri yang terbentuk dari pola asuh orang tua kepada anak. Konsep diri yang positif akan berpengaruh pada penghargaan diri anak yang positif, sehingga akan juga berpengaruh pada efikasi dirinya yang positif juga. Parenting ini biasanya sudah diterapkan sejak anak lahir dan disesuaikan dengan perkembangan si anak, Aulina, dkk (2018) menyebutkan contohnya pada anak usia dengan rentang usia 10-12 tahun. Dimana, pada usia tersebut termasuk dalam usia sekolah (6-12 tahun), yang mana usia tersebut memiliki berbagai karakteristik perkembangan seperti perkembangan kognitif, sosial, moral, dan biologis. Interaksi komunikasi antarpribadi antara 
orang tua dengan anak sangat dibutuhkan karena perkembangan dalam segi kognitif inilah yang menjadikan anak mulai berpikir secara rasional tentang mengenai banyak hal, termasuk yang berkaitan dengan dirinya. Fahruddin, dkk (2018) pada jurnalnya menyebutkan pendidikan parenting sangat diperlukan karena suatu proses dalam mengembangkan potensi individu sehingga memiliki kecerdasan intelektual dalam hal ini kecerdasan emosionalnya. Faktanya adalah anak untuk mengutarakan pendapat, pandangan mereka terkadang masih sulit untuk dilakukan. Tujuan dari parenting education ini terdapat 3 tujuan, yaitu: untuk meningkatkan kesadaran orang tua, meningkatkan pengetahuan dan keterampilan dalam hal mengasuh, dan mempertemukan kepentingan antara pihak keluarga dan pihak sekolah.

Sayangnya, belum semua orang tua menyadari hal ini dalam kegiatan pengabdian ini, Badan Eksekutif Mahasiswa bersama dosen Universitas Bakrie akan berbagi ilmu dan experience kepada masyarakat desa Karya Mekar, Kecamatan Cariu Kabupaten Bogor. Sebagai gambaran masyarakat yang tinggal di desa ini mayoritas sebagai petani, dari aspek pendidikan sebagian besar lulusan SD sampai dengan SMP, dimana mereka memilih untuk melanjutkan pekerjaan orang tuanya atau menikah muda. Sebagian besar masih terbilang muda dengan rentang usia 22-35 tahun mereka sudah memilki anak. Karakteristik masyarakat desa dengan kota bisa begitu berbeda, hal ini disebabkan adanya beberapa perbedaan signifikan terkait cara hidup sehari-hari dan sistem sosialnya. Salah satu contohnya adalah generasi muda yang tinggal di perkotaan akan lebih leluasa mengakses informasi, memiliki penampilan atau kesan yang terkadang malampaui usianya, memiliki sikap apatis yang tinggi, serta memilki keberanian berbicara bahkan beraksi sehingga kepercayaan diri yang mereka miliki tinggi. Beda halnya dengaan generasi muda yang tinggal di desa, kendalakendalanya adalah pada umumnya kesulitan mengakses informasi secara cepat karena infrastruktur untuk internet yang lebih cepat, mudah serta hemat belum tersedia, terbatas aliran listrik yang masuk. Kemudian, dari aspek penampilan dianggap lebih baik sebab mereka masih menjunjung tinggi adat, budaya kesantunan, dan norma. Namun, keberanian untuk menyampaikan pendapat terbatas karena faktor lingkungan dan budaya.

Dengan demikian, kegiatan ditujukan untuk berbagi ilmu mengenai pentingnya membangun hubungan antarpribadi antara orang tua dengan anak sejak dini, sehingga interaksi komunikasi antarpribadi yang terbina dapat membimbing dalam proses pembentukan konsep diri anak sejak usia dini, dimana pada masa golden age 08 tahun adalah masa emas anak untuk memberikan nilai-nilai yang positif. 


\section{Rumusan Masalah}

Setiap orang tua memilki cara untuk mendidik anak mereka, termasuk cara pola asuh. Namun terkadang orang tua tidak menyadari pola asuh seperti apa yang seharusnya diterapkan.

Parenting education memiliki peran yang penting dan utama pada diri anak. Kesadaran orang tua untuk membesarkan anak mereka, masih minim. Minimnya pengetahuan akan pemahaman bahwa membesarkan anak tidak cukup hanya dengan anak diberikan nutrisi vitamin dan makan yang sehat, namun perkembangan psikis dan mental sebagai pembekalan diri mereka di masa depan juga memiliki peranan.

Hal ini juga disampaikan oleh Akbar (2017) dalam jurnalnya yang berjudul "Program Peningkatan Keterlibatan Orang tua Melalui Kegiatan Senin Pada Anak Usia Dini" menuturkan bahwa keterlibatan orang tua sangat penting sebab, orang tua memberikan pengaruh pada keberhasilan anak. Selanjutnya, mengetahui bahwa kurangnya wadah informasi dan edukasi yang belum terfasilitasi mengenai parenting terhadap anak yang baik dan benar di desa Karya Mekar Kecamatan Cariu Kabupaten Bogor maka BEM bersama dosen Univesitas Bakrie akan melaksanakan kegiatan Pengabdian Kegiatan Masyarakat (PKM) yang bersifat diskusi antapribadi dengan para ibu muda. Selain itu juga, diberikan pemahaman bahwa peran orang tua disini berperan penting dalam mendampingi anak dalam proses tumbuh kembangnya. Hidayatullah (2017) menuliskan tingkat kesadaran yang dimiliki generasi muda masih memperihatinkan oleh karenanya dibutuhkan supporting system yang mendukung.

Tujuan diadakan kegiatan ini adalah untuk memberikan kesadaran bahwa peran orang tua bukan hanya dibebankan kepada ibu saja, namun diperlukan partner dalam membangun dan membina anak-anak mereka yakni peran ayah didalamnya. Selaras juga yang disampaikan oleh Akhyadi dan Mulyono (2018) mengatakan parenting adalah penguatan dalam kehidupan masyarakat, terutama pada perkembangan anak usia dini, diperlukan metode pengasuhan dan pola interkasi komunikasi dua arah disini. Dengan kata lain, anak-anak dipersiapkan bukan saja sebagai seorang anak saja, namun dibekali dan dipersiapkan anak laki-laki mereka untuk menjadi seorang pemimpin keluarga, memiliki tanggung jawab, serta memiliki komitmen yang tinggi, sedangkan anak perempuan mereka dipersiapkan dan dibekali untuk menjadi seorang ibu dan istri yang cerdas ketika membesarkan penerusnya nanti.

\section{TINJAUAN KEBIJAKAN DAN LITERATUR}

\section{Komunikasi Antarpribadi (Interpersonal Communication)}

Devito (2013) menjabarkan pemahaman mengenai komunikasi antarpribadi dalam 
bukunya dengan judul "The Interpersonal Communication" disebutkan interpersonal communication is the verbal and nonverbal interaction between two (or sometimes more than two) interdependent people. Kemudian disebutkan lebih lanjut bahwa interpersonal communication involves interdependent individuals. Interpersonal communication is the communication that takes place between people who are in some way "connected". Dengan kata lain, komunikasi antarpribadi merupakan interaksi komunikasi antarpribadi antara komunikator dengan komunikan, dimana dalam interaksi tersebut terjadi pertukaran informasi (pesan) yang bersifat verbal dan nonverbal, serta interaksi komunikasi antarpribadi melibatkan individu-individu yang saling bergantung.

Adapun prinsip-prinsip komunikasi antarpribadi meliputi beberapa hal menurut Paul Watzlawick, dkk (1967) dalam DeVito (2013) yakni terdiri:

1. Komunikasi antarpribadi adalah proses pertukaran (interpersonal communication is a transactional process), komunikasi antarpribadi sebagai proses sirkuler yang selalu berubah, segala sesuatu yang terlibat didalamnya yakni faktor-faktor yang memengaruhinya dapat berubah, seperti diri kita dapat berubah, orang-orang yang berkomunikasi dengan kita pun juga berubah, serta lingkungan turut berubah. Terkadang perubahan ini tidak selalu disadari, kadang juga dapat mengganggu secara jelas, namun hal ini selalu terjadi ketika interaksi komunikasi antarpribadi sedang berlangsung. Proses sirkuler disini adalah pesan satu orang individu berfungsi memberikan stimulus berupa pesan bagi orang lain, juga berfungsi memberikan stimulus untuk pesan orang pertama, dan seterusnya. Selama proses sirkuler (melingkar) ini berlangsung, maka setiao orang berfungsi secara bersamaan sebagai komunikator dan komunikan sekaligus, aktor dan reaktor, sehingga bisa dikatakan bahwa komunikasi antarpribadi adalah proses yang saling interaktif.

2. Komunikasi antarpribadi memiliki tujuan (interpersonal communication is purposeful), ketika menjalani interaksi komunikasi antarpribadi, selalu ada feedback nya yakni memiliki tujuan, terdiri dari untuk belajar (to learn), untuk memengaruhi (to influence), untuk berhubungan (to relate), untuk bermain (to play), dan untuk membantu (to help). Berikut penjelasannya:

a. To learn, komunikasi antarpribadi memungkinkan diri untuk belajar, dimana untuk lebih memahami dunia eksternal (dunia, peristiwa, dan orang lain). Ketika kita membaca Tweet dari followers, diri ini akan belajar tentang mereka dan dunia tempat mereka tinggal. Meski, banyak informasi berasal dari media yang mana bisa dijadikan bahan diskusi dan akhirnya 
mempelajari atau menginternalisasikan informasi tersebut melalui interaksi antarpribadi. Selanjutnya, melalui interaksi komunikasi ini kita juga belajar mengenai bagaimana diri ini berpenampilan kemudian siapa sajakah yang akan menyukai diri kita, atau sebaliknya yang tidak menyukai diri, dan mengapa nya.

b. To influence, saat kita melakukan interaksi komunikasi antarpribadi adalah hal yang sangat mungkin diri kita memengaruhi sikap dan perilaku orang lain.

c. To relate, dengan komunikasi antarpribadi dapat membantu diri kita connected dengan orang lain. Komunikasi adalah jantung dari salah satu kebutuhan terpenting bagi manusia, yakni untuk membangun dan memelihara hubungan yang dekat, menjalin silahturahmi.

d. To play, komunikasi antarpribadi bukan saja bertatap muka secara langsung, namun melalui media sosial pun juga termasuk dalam komunikasi antarpribadi. Dalam komunikasi online, mungkin bentuk permainan yang paling jelas adalah permainan interaktif di lingkungan realitas nyata atau virtual. Melalui prosesnya yang cukup menarik, pemain mengembangkan keterampilan yang berguna seperti mengasah kemampuan untuk mengambil perspektif orang lain. e. To help, merupakan tujuan untuk membantu orang lain yang bersifat emosional. Dengan kata lain, emosional disini bukan dalam bentuk amarah saja namun emosional yang dimaksud adalah ekspresinya. Ketika orang terdekat kita sedang bersedih, tentu butuh orang yang bisa memahami apa yang dirasakan, mencoba juga memahami apa yang dipikirannya.

3. Komunikasi antarpribadi memiliki ambigu (interpersonal communication is ambiguous),

Pesan ambigu merupakan sebuah pesan yang diartikan memiliki lebih dari satu makna. Wood (2011) menyampaikan terkadang ambiguitas terjadi karena orang menggunakan kata-kata yang dapat diartikan berbeda. Dengan mengasah keterampilan diri dalam melakukan komunikasi antarpribadi dapat dipandang sebagai sarana untuk mengurangi ambiguitas secara tepat dan menjadikan makna yang diungkapkan menjadi sejelas mungkin

4. Komunikasi antarpribadi mengacu pada konten dan hubungan (interpersonal communication refers to content and relationship),

Dalam dua komunikasi apa pun, dimensi konten mungkin sama, tetapi aspek hubungan mungkin berbeda, atau aspek hubungan mungkin sama dan dimensi konten berbeda. Artinya adalah pesan konten yang diangkat 
merujuk pada fakta aspek hubungan yang terjalin, yakni hubungan superior-inferior dimana ada izin untuk melakukan hal-hal tertentu yang tidak merugikan keduabelah pihak. Perlu diketahui, banyak masalah di antara orang-orang dihasilkan dari kegagalan untuk mengenali perbedaan antara konten dan dimensi hubungan komunikasi. Secara umum, dimensi konten relative dapat diselesaikan dengan mencari referensi dari buku, atau bertanya kepada seseorang yang mengetahui duduk persoalannya yang sedang terjadi. Argumen pada tingkat hubungan, bagaimanapun jauh lebih sulit untuk diselesaikan, sebab sebagian dari kita mungkin tidak mengetaui bahwa argumen tersebut adalah argumen yang relasional.

5. Komunikasi antarpribadi tidak dapat dihindarkan, tidak dapat diulang, dan tidak terbalik (interpersonal communication is inevitable, irreversible, and unrepeatable),

Dalam interaksi komunikasi antarpribadi terdapat prinsip tak terhindarkan yang berarti ketika interaksi terjadi, kita secara tidak sadari kita melakukannya yakni perilaku yang secara spontan bisa dilakukannya. Wardhani (2016) juga menyampaikan diperlukan keterampilan komunikasi yang baik dalam program parenting. Misal, saat anak sedang berbicara serius tentang moment yang dihadapinya, lalu respon orang tuanya kurang menyimak yakni memandang kearah yang lain atau memberikan respon pada pesan yang masuk di Hp. Hal ini, dapat diartikan cerita yang disampaikan oleh anaknya membosankan bagi orang tuanya. Komunikasi antarpribadi tidak dapat diubah, yakni kualitas tidak dapat dibalikkan ini berarti bahwa apa yang kita komukasikan harus tetap dikomunikasikan.

Dari penjelasan diatas tentang beberapa tujuan komunikasi antarpribadi dapat disimpulkan bahwa dalam komunikasi antarpribadi rentan terjadinya konflik maka harus sangat hati-hati agar tidak mengatakan pada hal-hal yang tidak dapat ditarik nantinya, agar memperoleh komunikasi yang efektif, dibutuhkannya keterbukaan, rasa empati, dukungan, rasa positif dan merasa setara. Pentingnya dari komunikasi antarpribadi itu sendiri ialah dapat membantu pengembangan intelektual dan sosial manusia, serta membentuk identitas diri kita yang terbentuk melalui interaksi diri dengan orang lain, dan kesehatan mental diri sebagian besar juga ditentukan oleh kualitas komunikasi atau hubungan antarpribadi.

\section{Konsep Diri}

Sebelum masuk pada konsep diri, pemahaman diri (self) dulu. Menurut Tangney, dkk dalam buku "Psikologi Sosial" yang ditulis oleh Rahman (2017) disebutkan ada lima cara bagaimana para pakar dalam bidang sosial dan perilaku memahami self dan unsur-unsurnya. Pertama, self dipandang sebagai total person. 
Kedua, self dipandang sebagai kepribadian. komponen yang sifatnya stabil disebut selfKetiga, self dipandang sebagai subjek yang verification theory dari Swann, yang menyatakan mengalami (as experiencing subject). Keempat, konsep diri seseorang terbentuk secara pasti, dan self dipandang sebagai executive agent. individu tersebut akan mengusahakan beberapa Selanjutnya yang kelima, self dipandang sebagai strategi kognitif dan behavioral untuk persepsi, pikiran, dan perasaan terhadap diri mempertahankannya. Selaras juga yang sendiri.

Dalam prosesnya pengenalan diri ini disampaikan oleh Akhyadi dan Mulyono (2018) mengatakan parenting adalah penguatan dalam membutuhkan waktu yang tidak singkat, usaha kehidupan masyarakat, terutama pada diri untuk memahami diri kita sendiri menghasilkan konsep kita mengenai diri kita sendiri, yang disebut sebagai konsep diri. Branden (1983) pada bukunya "Honoring TheSelf' dalam Rahman (2017:62) mendefinisikan konsep diri sebagai pikiran, keyakinan, dan kesan seseorang tentang sifat dan karakteristik dirinya, keterbatasan dan kapabilitasnya, serta kewajiban dan asset-aset yang dimilikinya. Selanjutnya, Campbell (1981, dalam Kernis \& Goldman, 2003) dalam buku "Psikologi Sosial" yang dituliskan oleh Rahman (2017: 63) menyebutkan selfconcept clarity, adalah satu faktor penting yang memiliki pengaruh besar terhadap perubahan konsep diri, yakni sejauh mana konsep diri seseorang itu secara internal konsisten, stabil, dan dipegang dengan penuh keyakinan. perkembangan anak usia dini, diperlukan metode pengasuhan dan pola interaksi komunikasi dua arah disini.

DeVito (2013) menyebutkan konsep diri kita berkembang dari empat sumber yakni (1) citra diri kita yang dimiliki orang lain terhadap kita, dan yang mereka ungkapkan kepada diri kita (others image) (2) perbandingan yang diri kita buat antara diri sendiri dan orang lain, yang disebut dengan perbandingan sosial (social comparasions) (3) ajaran budaya kita (cultural teachings), dan (4) cara kita menafsirkan dan mengevaluasi pikiran dan perilaku diri sendiri (self-eavluations). Rakhmat (2018) dalam bukunya yang berjudul "Psikologi Komunikasi edisi Revisi" menyebutkan ada faktor-faktor yang memengaruhi konsep diri yakni:

Selanjutnya, hasil penelitian Campbell 1. Orang Lain, menunjukkan hubungan antara rendahnya selfconcept clarity dengan rendahnya self-esteem, akan menyebabkan tingginya tingkat depresi, serta tingginya tingkat kecemasan dirinya. Konsep diri yang kita miliki ini, memiliki beberapa

Cara kita mengenal diri sendiri adalah kita mengenal diri kita dengan mengenal orang lain lebih dahulu. Tidak semua orang lain mempunyai pengaruh yang sama terhadap diri kita, namun ada yang paling berpengaruh 
yaitu orang-orang terdekat disebut significant others. Dewey, dkk (1966:105) dalam Rakhmat (2018) menamainya affective others, yakni orang lain yang memiliki ikatan emosional dengan kita, dan dari mereka inilah secara perlahan-lahan kita membentuk konsep diri. Mead (1863-1931) dalam Rakhmat (2018) juga menambahkan padangan diri kita tentang keseluruhan pandangan orang lain terhadap diri, disebut generalized others. Misalnya, mengambil peran sebagai ibu, sebagai ayah, atau sebagai generalized others disebut dengan role taking, dimana role taking ini juga berperan penting dalam proses pembentukan konsep diri seseorang.

2. Kelompok Rujukan (Reference Group),

Dalam proses pembentukan konsep diri kelompok rujukan juga turut berperan. Ketika, individu beranjak usia, ruang lingkupnya bukan hanya keluarga saja namun seorang individu juga turut memperluas ruang lingkupnya untuk mengikuti suatu komunitas atau kelompok, sebagai representative dirinya. Setiap kelompok mempunyai normanorma tertentu, ada kelompok yang secara emosional mengikat dan berpengaruh terhadap pembentukan konsep diri kita. Inilah yang disebut sebagai kelompok rujukan.

\section{Kebijakan dan Undang-Undang}

Anak merupakan bagian yang tidak bisa dipisahkan dari keberlangsungan hidup manusia dan keberlangsungan sebuah bangsa dan negeri. Mengingat anak merupakan penerus generasi bangsa, maka dari itu anak perlu mendapatkan kesempatan untuk tumbuh dan berkembang secara optimal, baik fisik, mental maupun sosial. Kita tahu bahwa negara Indoenesia sangat menjunjung tinggi hak asasi manusia, termasuk di dalamnya mengenai hak asasi Anak yang ditandai dengan adanya jaminan perlindungan dan pemenuhan Hak Anak dalam Undang Dsar Negara Republik Indonesia Tahun 1945, serta ketentuan peraturan perundangan-undangan baik dalam skala nasional, maupun internasional. Hal ini selaras dengan isi Undang Undang Republik Indonesia Nomor 35 Tahun 2014 atas perubahan Undang Undang Nomor 23 Tahun 2002 mengenai Perlindungan Anak. Adapun isi dari Undang Undang Republik Indoenesia Nomor 35 Tahun 2014, pasal 1 menyatakan:

"Perlindungan Anak adalah segala kegiatan untuk menjamin dan melindungi Anak dan hak-haknya agar dapat hidup, tumbuh, berkembang, dan berpartisipasi secara optimal sesuai dengan harkat dan martabat kemanusiaan, serta mendapat perlindungan dari kekerasan dan diskriminasi..."

Dalam hal ini, anak berhak mendapat pola asuh yang tepat dari keluarga, dimana keluarga 
merupakan unit terkecil dalam masyarakat yang terdiri dari suami, istri, dan anak, atau ayah dari anak, maupun ibu dari anak. Adanya Undang Undang Republik Indonesia Nomor 35 Tahun 2014 ini dikeluarkan, menimbang bahwa Negara Kesatuan Republik Indonesia berupaya dalam menjamin kesejahteraan tiap warga negaranya, termasuk pada perlindungan terhadap anak yang merupakan bagian dari warga yang juga memiliki hak asasi manusia. Tidak hanya itu, anak memiliki peran sebagai tunas, potensi, dan generasi muda penerus cita-cita perjuangan bangsa yang perlu dilindungi. Maka dari itu peran orang tua dalam membentuk karakter, memberikan pola asuh kepada anak secara tepat, sangat berpotensi untuk mengoptimalkan dalam proses tumbuh kembang anak.

\section{GAMBARAN UMUM}

Kegiatan ini berlangsung di Desa Karya Mekar, Kecamatan Cariu, Kabupaten Bogor, Jawa Barat. Peserta yang mengikuti kegiatan PKM dengan nama kegiatan "Hayu Urang Ngobrol, Dak..." ini ialah orang tua khususnya Ibu dari si Anak. Usia para Ibu di Desa Karya Mekar ini masih terbilang muda sekitar 22-35 tahun, dengan latar belakang pendidikan hanya sampai dengan menempuh pendidikan SMP (Sekolah Menengah Pertama). Sesuai dengan pernyataan dari partisipan atau peserta kegiatan PKM "Hayu Urang Ngobrol, Dak..." ini, para Ibu di Desa Karya Mekar ini memutuskan untuk menikah setelah menempuh pendidikan SMP dikarenakan adanya faktor dorongan dari orang tua mereka yang menuntut untuk segera menikah. Hal ini merupakan salah satu faktor yang menyebabkan para orang tua di Desa Karya Mekar kurang bisa memberikan pola asuh yang tepat kepada anakanaknya. Maka dari itulah, kegiatan PKM ini dilaksanakan untuk memberikan kesadaran, dan pemahaman kepada orang tua, bahwa peran orang tua baik Ibu maupun Ayah untuk membina anak, serta mendidik anak melalui pola asuh yang baik dan tepat sangat diperlukan.

\section{METODE KEGIATAN PKM}

Dari rumusan masalah yang telah diuraikan sebelumnya, maka metode kegiatan PKM ini menggunakan konsep diskusi interaktif. Terdapat tiga tahapan yakni:

1. Tahap persiapan,

Tahap persiapan adalah tahap awal sebelum dilakukannya pelaksanaan kegiatan. Dilakukan survey dan observasi ke desa Karya Mekar Kecamatan Cariu Kabupaten Bogor. Bertemu dengan pihak yang terkait yakni Kepala Desa (Kades) Karya Mekar, melakukan brainstorming mengenai hal-hal apa yang saja yang dibutuhkan, agar materi yang disampaikan tepat. Dengan latar belakang partisipan adalah masyarakat lokal serta fasih dengan menggunakan bahasa Sunda sebagai bahasa yang digunakan dalam kehidupan mereka sehari-hari maka kegiatan pengabdian 
ini memerlukan translator yang berperan untuk menjembatani antara pemateri dengan pasrtisipan. Kemudian, pemilihan kalimat dalam penyampaian harus dibuat mudah dipahami, karena latar belakang pendidikan partisipan adalah tamat SD namun tidak tamat SMP. Selain itu, media untuk memaparkan materi sulit untuk ditampilkan dengan power point, oleh karenanya dibutuhkan kecapakapan komunikasi dalam proses penyampaian materi.

2. Tahap pelaksanaan,

Pada tahapan ini, dalam pelaksanaan kegiatan dimulai dari jam 10.00 hingga jam 12.00. konsep kegiatan pengabdian dikemas dengan sharing session yang artinya pemateri akan menyampaikan materinya dengan sesi berbagi pengalaman antara pemateri dengan partisipannya. Posisi duduk ketika kegiatan berlangsung dibuat dalam bentuk lingkaran, hal ini bertujuan agar partisipan merasa relaks dan santai dalam menerima materi yang disampaikan oleh pemateri. Selama kegiatan berlangsung dibutuhkan translator, untuk bisa mengintepretasikan tentang materi yang disampaikan. Kemudian, dalam tahap pelaksanaan ini juga dilakukan diskusi interaktif, dimana tidak hanya materi saja yang disampaikan namun partisipan boleh menananyakan langsung apa yang mereka bingung atau ketidaktahuannya.

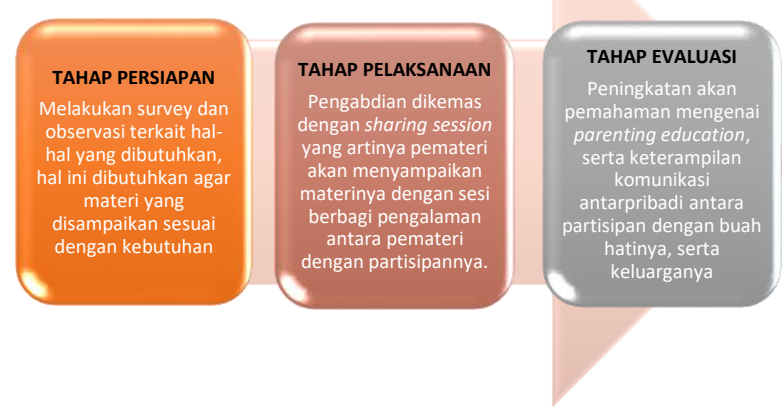

Gambar 1. Alur Kegiatan Pengabdian "Hayu Urang Ngobrol, Dak..." Mengenai Implementasi Pembentukan Self Concept Melalui Komunikasi Antarpribadi Antara Orangtua Dengan Anak

3. Tahap evaluasi,

Dalam tahap evaluasi, dilakukan evluasi atas hasil yang telah dicapai oleh partisipan. Masukan dan perbaikan lebih lanjut dapat dilakukan pada tahap ini, selain itu diharapkan juga melalui kegiatan PKM yang dikemas melalui diskusi interaktif dapat menambah wawasan parenting education serta keterampilan komunikasi antarpribadi antara partisipan dengan buah hatinya, selain itu diharapkan juga mampu membangun hubungan antrpribadi dengan keluarganya.

Adapun kriteria kegiatan dalam pengabdian ini adalah:

1. Pemateri menguasai ilmu komunikasi keluarga, komunikasi antarpribadi, serta psikologi komunikasi.

2. Jenis kegiatan pengabdian ini adalah diskusi interaktif dengan konsep interactive experience sharing.

3. Terdapat sesi diskusi dan sharing, dimana pada kesempatan ini partisipan dapat 
menyampaikan masalah atau kendala Universitas Bakrie serta para volunteer, maka personal.

4. Partisipan dalam kegiatan ini adalah ibu muda usia 22-35 tahun, dengan latar belakang pendidikan tamat SD.

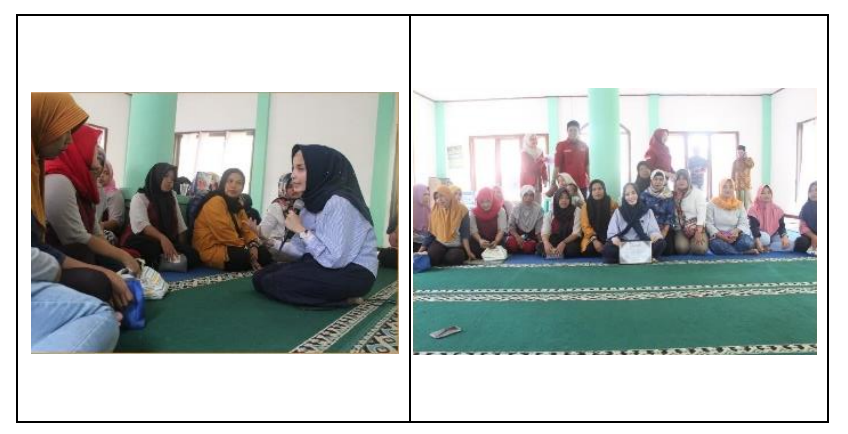

Gambar 2. Foto Bahan Produksi Kegiatan Pengabdian "Hayu Urang Ngobrol, Dak..." (Sumber: dokumentasi penulis)

\section{PEMBAHASAN}

Usai dijelaskan dari uraian di atas, terkait dengan topik yakni edukasi implementasi pembentukan konsep diri melalui komunikasi antarpribadi antara orang tua dengan anak pada kegiatan pengabdian "Hayu Urang Ngobrol, Dak...", dilakukan melalui tiga tahapan sebagai berikut:

\section{Tahap Persiapan}

Pada hari Sabtu, 13 April 2019, kegiatan pengabdian "Hayu Urang Ngobrol, Dak..." diselenggarakan tepatnya di Masjid desa Karya Mekar, dekat sekolah PAUD dimana pada saat itu, orang tua sedang berkumpul disana sekaligus menunggu anak mereka yang sedang belajar melukis yang diajarkan oleh para panita pengabdian. Semula kegiatan edukasi ini akan dilaksanakan di balai desa, dikarenakan balai desa dijadikan tempat tinggal bagi panitia BEM kegiatan parenting education dipindahkan ke Masjid desa Karya Mekar. Kegiatan ini dilaksanakan sebagai bentuk wadah informasi serta edukasi bagi para orang tua mengenai cara memberikan pola asuh yang baik, serta memberikan pemahaman bagaimana cara berkomunikasi yang baik kepada anak.

Penyampaian materi yang dibawakan berupa diskusi antarpribadi secara interaktif dimana, pembicara tidak hanya menyampaikan materi namun peserta diajak berperan aktif untuk bertanya serta sharing mengenai beragam kendala yang dihadapi ketika menghadapi si anak. Selama diskusi antapribadi dengan peserta, pemateri dibantu dengan adanya translator dari pengurus BEM Universitas Bakrie yang ahli menggunakan bahasa Sunda untuk menjembatani komunikasi antara pemateri dengan audience, tujuannya adalah untuk meminimalisir kesalahpahaman pesan yang dimaksudkan dan yang menerima pesan bisa memahami tentang materi yang disampaikan.

\section{Tahap Pelaksanaan}

Kegiatan yang berlangsung selama 2,5 jam ini dihadiri oleh ibu-ibu muda yang anak mereka sedang mengembang pendidikan SD, rentang usia 22-35 tahun. Kegiatan ini dihadiri 20 partisipan. Berlangsungnya kegiatan ini, partisipan merasa malu untuk mengutarakan kendala yang dihadapi, sehingga pemateri perlu menciptakan iklim komunikasi yang kondusif 
terlebih dahulu dengan pendekatan secara personal disertai canda tawa. Dengan konsep sharing session yang dikemas interactive experience sharing, maka pemateri memberikan pengalamannya sebagai seorang ibu yang membangun hubungan antarpribadi dengan anak, disinilah proses keterbukaan diri terjadi pasrtisipan secara perlahan bisa membuka dirinya, selain itu berbagi pengalaman ini disertai dengan ilmu komunikasi antarpribadi dan psikologi komunikasi. Mengajari kepada para ibu untuk lebih bersabar dan menyimak terlebih dahulu apa yang diinginkan oleh buah hatinya.

Pemateri membagi ilmunya terkait dengan teori dasar komunikasi yakni siapa yang menjadi komunikator, siapa yang menjadi komunikannya, lalu bagaimana cara penyampaian pesannya pada buah hatinya. Disini yang dimaksudkan adalah interaksi komunikasi orang tua dengan anak, dimana orang tua sebagai komunikatornya dan anak sebagai komunikan. Dalam interaksi tersebut peran orang tua tidak selalu menjadi komunikator saja, namun orang tua juga sebagai komunikannya. Pembicara memberikan metode I-language dengan diimplementasikan pada diri orang tua terlebih dahulu dengan memilih ungkapan yang positif atau kontruktif sebelum pesan disampaikan kepada anak. Hal ini menjadi indikator utama bagi orang tua sebelum memulai interaksi komunikasi dengan anak.

Sebelumnya telah disampaikan bahwa partisipan atau peserta masih malu untuk membuka diri. Agar peserta menjadi relaks dapat dengan mudah mereka bisa menyerap ilmunya. Maka, pemateri menciptakan iklim komunikasi yang kondusif dengan menerapkan teori dasar ilmu komunikasi $5 \mathrm{~W}+1 \mathrm{H}$ yakni pemateri lebih dulu menceritakan berbagai pengalaman mengenai parenting education. Sehingga, peserta mulai menunjukkan antusias dengan menceritakan pengalaman internalnya.

Terkait dengan psikologi komunikasinya, menggunakan pendekatan sistem komunikasi antarpribadi dimana dalam interaksi komunikasi ini terjadi pertukaran simbol-simbol antara komunikator dengan komunikannya. Jika komunikasi yang diciptakan antara ibu dengan buah hatinya baik maka buah hati akan bisa dengan baik juga menerima pesan dari ibunya. Hal yang pertama dibangun diawal adalah membangun trust dengan anak, agar anak tidak merasa bahwa orang tuanya adalah ancaman bagi mereka. Jika dalam penyampaian pesannya selalu menggunakan kalimat ancaman, kalimat buruk dan negatif maka akan berpengaruh terhadap pembentukan konsep diri anak.

Pemateri mengingatkan bahwa masa golden age pada anak usia 0-8 tahun adalah usia emas mereka. Disini, anak-anak daya rekam, masa imitasi sedang terjadi. Lebih lanjut lagi, pemateri mengingatkan kepada partisipan bahwa masingmasing anak memiliki karakateristiknya sehingga anak tidak bisa disamakan, pendekatannya pun berbeda, dan diingatkan juga untuk tidak 
membandingkan diantara mereka. Jika dilakukan dengan continue maka akan membentuk anakanak menajdi tidak percaya diri, penghargaan diri mereka menjadi negatif, murung, dan efikasi diri mereka juga berpengaruh menjadi negatif. Hal ini akan berimplikasi terhadap masa remaja hingga dewasanya nanti, mereka akan tumbuh menajdi individu yang tertutup, serta sulit sekali untuk menemukan apa yang menjadi minat dan bakat mereka. Dengan kata lain, anak-anak ini akan mengulang kembali apa yang sudah dilakukan oleh orang tuanya, padahal orang tua mengharapkan anak-anak mereka tidak seperti mereka.

\section{Tahap Evaluasi}

Akhir dari materi, pemateri memberikan tips bagi orang tua yang masih muda dan belum memiliki pengetahuan mengenai parenting, dengan tujuan agar dapat mendidik anak mereka dengan baik dan penuh kasih, sebagai berikut:

1. Orang tua berpandangan positif bagi anak.

2. Tanamkan rasa saling menghargai dan menghormati, dengan menghindari ungkapan buruk.

3. Anak adalah peniru ulung.

4. Kepribadian anak dibentuk atas dasar pola asuh yang dibentuk oleh orang tuanya.

5. Tidak perlu malu untuk menyampaikan terima kasih, dan maaf kepada anak.

Selain tips yang diberikan oleh pemateri kepada para ibu-ibu yang masih muda ini, selama kegiatan berlangsung seperti yang sudah disampaikan pada tahap sebelumnya, para peserta masih sangat malu dan enggan untuk membuka diri, untuk menciptakan iklim komunikasi (climate communication) yang kondusif selama kegiatan pengabdian berlangsung membutuhkan waktu lebih agar mereka berani untuk menyampaikan pola interaksi komunikasi antarpribadi yang dibangun dalam keluarganya. Oleh karena itu, beberapa faktor yang memengaruhinya yakni faktor budaya budaya, melatarbelakangi para ibu-ibu muda ini untuk mau berbagi cerita dan pengalamannya, namun bagi ibu-ibu yang sudah senior usianya mereka berani untuk sedikit membuka cerita terkait hambatan komunikasi yang dialaminya. Faktor pendidikan, adanya budaya yang masih kental tersebut pendidikan bukan menjadi yang utama.

Terlihat dari, usia peserta yang turut serta dalam kegiatan pengadbian ini masih tergolong muda, mereka memutuskan untuk menikah dalam usia muda hal ini karena permintaan dari orang tua, selain itu banyak dari peserta juga tidak menamatkan sekolah tingkat menengah (SMP), bahkan beberapa diantara mereka juga tidak selesaikan Sekolah Dasar (SD) nya. Sehingga, pengemasan materi yang dikemas harus sederhana dan sangat mudah dicerna, karena tidak adanya ruang pertemuan yang memadai untuk menampilkan materi melalui power point (PPT) ataupun pemutaran video, maka surau (musholah) dijadikan tempat 
kegiatan pengabdian ini. Selanjutnya adalah faktor bahasa, juga turut menjadi obstacle (hambatan) saat kegiatan pengabdian berlangsung, sehingga penyamaan persepsi yang sama antara pemateri dengan peserta membutuhkan perantara untuk bisa menjembatani pesan yang disampaikan oleh pemateri kepada peserta dalam kegiatan pengabdian ini.

Selama kegiatan pengabdian berlangsung terlihat perubahan peserta yang sebelumnya mereka masih enggan atau malu untuk mengutarakan masalah internal keluarga dalam hal ini interaksi dengan anak, hubungan antarpribadi yang berjarak dengan anak, lalu kurangnya pengetahuan teori dasar ilmu komunikasi $5 \mathrm{~W}+1 \mathrm{H}$ yang berperan penting dalam menciptakan iklim komunikasi yang intim di ruang lingkup keluarga. Lalu, setelah peserta mengikuti kegiatan ini peserta mampu membuka diri untuk menjelaskan pengalaman yang dialami oleh mereka, disinilah interactive experience sharing terjadi melalui antusias peserta terhadap kegiatan ini.

\section{KESIMPULAN}

Berdasarkan hasil kegiatan pengabdian di desa Karya Mekar Kecamatan Cariu Kabupaten Bogor tentang parenting education, peserta antusias dalam kegiatan ini hal ini terlihat dari pertanyaan-pertanyaan yang diajukan, meskipun ada sedikit kendala dalam bahasa, namun translator bisa menjembatani komunikasi antara pemateri dengan pesertanya. Pemilihan kalimat yang digunakan selama kegiatan ini dipilih kalimat yang mudah dipahami dan dapat diingat sehingga dapat dilakukan oleh partisipan usai mengikuti kegiatan interactive experience sharing dengan konsepnya sharing session. Dengan partisipan bisa membuka diri mereka, diketahui bahwa masih minim ilmu parenting yang dimilikinya, dimana pihak perempuan dibebankan untuk membesarkan anak kemudian ayah yang menjadi pekerja.

Membangun pola asuh secara bersama belum diterapkan, hal ini karena masih terbentur oleh budaya yang melekat di desa tersebut. Mengetahui bahwa partisipan yang hadir adalah mereka yang menikah muda, disebut sebagai young parents, maka kematangan secara emosional belum matang sehingga ini juga menjadi faktor mengapa pola asuh yang diterapkan belum benar. Oleh karena itu, disarankan untuk kegiatan pengabdian selanjutnya, bisa memberikan pelatihan komunikasi keluarga dan psikologi komunikasi khusus untuk orang tua yang masih usia muda dengan anak mereka.

Karakteristik orang tua dengan usia muda memiliki kematangan emosi yang belum stabil, sebab para wanita pada usia ini dituntut untuk dapat mengasuh anak-anak, mengerjakan pekerjaan rumah tangga, melayani seorang suami, dan sebagainya. Usia yang masih muda 
tersebut menimbulkan kekurangan emosi Akhyadi, Ade Sadikin \& Mulyono, Dinno. (2018). sehingga banyak ibu-ibu muda yang mengalami kesulitan dalam mengatasi masalah-masalah yang timbul dalam rumah tangganya. Kurang stabilnya dalam aspek emosi ini akan menjadi pemicu permasalahan dalam rumah tangga seperti pertengkaran, perbedaan pendapat yang dapat menciptakan jurang atau gap yang besar dalam hubungan suami istri, sehingga akan memengaruhi pola asuh pada anak-anak mereka.

\section{UCAPAN TERIMA KASIH}

Terima kasih kepada Lembaga Pengabdian Masyarakat Universitas Bakrie yang telah memfasilitasi dalam pelaksanaan kegiatan PKM ini, lalu terima kasih pada BEM Universitas Bakrie yang sudah melibatkan dosen Universitas Bakrie untuk turut berpartisipasi dalam kegiatan mereka. Kemudian terima kasih juga pada partisipan para ibu muda di desa Karya Mekar, Kecamatan Cariu kabupaten Bogor, dengan kesadaran diri mereka turut serta dalam kegiatan ini.

\section{DAFTAR PUSTAKA}

Akbar, Zarina. (2017) Program Peningkatan Keterlibatan Orangtua Melalui Kegiatan Seni Pada Anak Usia Dini (Art Programs to Increase Parent Involvement in Early Childhood). Jurnal Pengabdian Kepada Masyarakat, 14(1), 53-60.

Program Parenting Dalam Meningktakan Kualitas Pendidikan Keluarga (Program Pengabdian di Desa Karangpakuan Kecamatan Darmaraja Kabupaten Sumedang). Jurnal Pengabdian Kepada Masyarakat (Abdimas) IKIP Siliwangi, 1(1). 18.

Arumsari, C., Nurkamilah, M., Isti'adah, F.N. (2018). Pembinaan Parenting bagi Orang Tua Siswa di PAUD dan TK ASSAABIQ Singaparna Kabupaten Tasikmalaya. ABDIMAS UMTAS: Jurnal Pengabdian Kepada Masyarakat, 1(1). 14-22.

Aulina, C.N., Rezania V.D., Evi. (2018). Pengabdian Kepada Masyarakat Melalui Pendampingan Bagi Guru POS PAUD. Jurnal ABDI: Media Pengabdian Kepada Masyarakat, 3(2), 41-45.

Devito, Joseph A. (2013). Interpersonal Communication Thirteen Edition. New York: Pearson

Fahrudin, A \& Baiq, N. (2018). Pelatihan Program Parenting untuk Meningkatkan Profesionalisme Guru PAUD Di Kota Mataram Tahun 2018. Jurnal Pengabdian Magister Pendidikan IPA 1(1). 37-44.

Hidayatullah, Achmad. (2017). Pendampingan Pendidikan Anak di Kelurahan Genteng Surabaya. Aksiyoga: Jurnal Pengabdian Masyarakat, 1(1), 45-51. 
Khoiri, A. (2016, April 14). Sebagian Besar Anak Sutherland, E. \& Donald R. C. (1960). Principles of Indonesia 'Salah Asuh'. CNN Indonesia. Criminology, Sixth Edition. Chicago: Jp Diakses dari https://www.cnnindonesia.com Lipponscott Company. /gaya-hidup/20160413202151-255-123787 /sebagian-besar-anak-indonesia-salah-asuh

Puspitawati H. (2008). Pengaruh faktor keluarga, lingkungan teman dan sekolah terhadap kenakalan pelajar di Sekolah Lanjutan Tingkat Atas (SLTA) di Kota Bogor. Jurnal Ilmiah Pekerja Sosial, 7(2), 247-275.

Rahman, A.A. (2017). Psikologi Sosial (Integrasi Pengetahuan Wahyu dan Pengetahuan Empirik). Jakarta: Rajawali Pers.

Rakhmat, Jalaludin. (2018). Psikologi Komunikasi (Edisi Revisi). Bandung: PT. Remaja Rosdakarya.

Silalahi, K \& Meinarno, E. A. (2010). Keluarga Indonesia: Aspek dan Dinamika Zaman. Jakarta: PT. Raja Grafindo Persada.
Thalib, SB. (2010). Psikologi Pendidikan Berbasis Analisis Empiris Aplikatif. Jakarta: Kencana Prenada Media Grup.

Wardhani, Wahju Dyah Laksmi., (2016). Memperbaiki Keterampilan Komunikasi Dalam Program Parenting. Jurnal Pengabdian Masyarakat Ipteks. 2(2), 75-81. Wiratri, Amorisa. (2018). Menilik Ulang Arti Keluarga pada Masyarakat Indonesia (Revisting The Concept of Family in Indonesian Society). Jurnal Kependudukan Indonesia, 13(1), 15-26.

Wood, Julia T., (2011) Communication Mosaics: An Introduction to The Field of Communication. Wadsworth Cengage Learning. 